\title{
Artigo
}

\section{Brazil's strategic partnerships: an assessment of the Lula era (2003-2010)}

Parcerias estratégicas do Brasil: um balanço

da era Lula (2003 - 2010)

ANTÔNIO CARLOS LESSA*

Rev. Bras. Polít. Int. 53 (special edition): 115-131 [2010]

\section{Introduction}

During President Lula da Silva's two terms in office (2003-2010), Brazilian diplomacy worked to reinforce the country's relations with its traditional partners, particularly the United States, Japan, and Western Europe, but also assigned priority to establishing new dynamic axes, as illustrated by the pursuit of partnerships with countries such as South Africa, India, and China. These adjustments and fine-tuning of bilateral relations laid the foundation of universalism in Brazilian foreign policy, as well as defining major lineaments for the country's international performance, namely, consolidation of economic relations (from the standpoint of trade currents and investment flows) and closer political cooperation at the highest level.

Starting from an analysis of the idea of "strategic partnerships" and of how it evolved through Brazil's international experience, this article will assess the development of this concept in recent years. The purpose is to stress the importance of the effort toward diversification and the sophistication of the political and economic ties with a view to the strategy for Brazil's incorporation into the international scene, as well as seeing how it relates to other movements, such as the pursuit of a permanent seat on the United Nations Security Council.

\section{A complex incorporation into the international scene}

The years that separate the end of the Cold War and the attacks of September 2001 constituted a peculiar moment in international life. While free trade and democracy asserted themselves as supreme values for the organization of the

\footnotetext{
* Professor at University of Brasília - UnB, Brazil, and researcher of National Council for Scientific and Technological Development - CNPq (alessa@unb.br).
} 
economies and for the political life of the National States, there also occurred the emergence of new political operating modes among nations and of new issues that rapidly became central to International relations.

There occurred a drastic oscillation in the behavior of the central actors in international relations, especially of the United States, as well as a tendency to value political and economic multilateralism, including the establishment or sophistication of regionalization projects. At the same time, on the international agenda predominated new issues, such as human rights, the environment and environmental governance, sustainable development, fair trade, energy, food security, new security issues raised by defense challenges, nuclear nonproliferation, democracy, and migration, among others.

The way these issues have evolved since, their modes of operation and particularly the way they have influenced each other were fundamental for determining all relevant countries' strategies of incorporation into the international scene, as well as conditioning their economic development strategies. This was particularly the case of Brazil's integration into the international scene, which has been complex and not free of hesitations and oscillations.

After a decade of experiments in foreign policy, which led first to the reversion of traditional behavior patterns, the shrinking of the diplomatic network, and the depleting of the bilateral contact assets, and especially to the valorization of multilateralism, these experiments gave rise to a new formula as of 2000 but particularly as of 2003. Firm action in multilateral spaces had its counterpart in the reconstruction of geographic universalism, which in turn acquired a new sense of priority. The revaluing of priority bilateral contacts, which in Brazilian traditional diplomatic praxis are known as "strategic partnerships," forms part of this new pattern. As a result, new dynamism has been injected into the economic expansion process, the trade and investment flows, and a new capacity of political coordination was achieved.

Changes in the international scene since the 2000s and the change in the perception of the great emerging markets have greatly influenced the conditions of Brazil's international visibility. The perpetuation of the country's firm command on economic stability strategy has also contributed to project the image of a large, stable mass consumption market. On the international scene, Brazil has displayed an assertive profile, as seen for instance in the determination with which diplomacy has aimed at a protagonist role in the unfolding of negotiations in respect of the most diverse issues on the contemporary agenda.

The direct and indirect consequences of the events since 9/11 have had a decisive impact on the setting of new priorities on the global security agenda, and have shown the need to reinforce multilateralism and strengthen multipolar international order. In the economic sphere, the pressing need for a new form of trade liberalization led to the launching of another round of trade negotiations under the auspices of the World Trade Organization-WTO. On the environmental 
agenda, the impact, risks, and costs stemming from climate change, which has become more evident in recent years, have called the attention of the governments of some of the rich countries to the need of giving priority to cooperation in the search for alternative energy sources.

The intertwining of these three new agendas has created a unique opportunity for Brazil, whose government has since 2003 enthusiastically sought more room for South-South and North-South political coordination. Though its chances to act as a protagonist in respect of the global security agenda were meager, the same cannot be said in relation to the debate regarding the legitimacy of contemporary international policy and the need of reforming and valorizing multilateral institutions.

Still in 2003, at the World Trade Organization Conference in Cancún, Brazil took the leadership of the emerging countries, in opposition to the historical practice whereby the rules of international trade are negotiated and decided by the developed countries. The formation of the Group of 20 (G-20) and then the mandate as negotiator in WTO's Doha Round were moments when the new group sought to condition the opening of the services and industrial markets of southern countries to the corresponding opening of the northern countries' agricultural markets.

In respect to the climate change agenda, Brazil does not act as an actual protagonist but as a holder of significant assets. The country's technological development and especially its many competitive advantages regarding biofuels production chain are factors of the innovating profile it displays in international action, with significant repercussions on its agenda of cooperation with both northern and southern countries.

In the regional sphere, Brazil's leadership role has become more prominent, although contested by some neighbors, particularly Venezuela and Argentina. In addition, the Brazilian government has demonstrated concern over regional political developments and has involved itself in stabilization experiences, as illustrated by its participation in the United Nations Stabilization Mission in Haiti.

In addition, it has sought a new modus operandi on different chessboards of contemporary international policy. The dedication with which Brazilian diplomacy has sought new coalitions, established around new issues and agendas, is an indication of an instigating vision. These coalitions include the IBSA Forum, formed by India, Brazil, and South Africa, and the Group of 4, formed by Brazil, Japan, Germany, and India to fight for the reform of the United Nations institutions. These coalitions were attempts to coordinate two sets of ideas:

1. The worldview of a country that sees itself as a regional power on a peaceful ascent, a major emerging market, a promoter of a genuinely multipolar international order, under which multilateral spaces are an essential condition; and

2. A bold view of international policy and an essentially positive reading according to which current international circumstances favor a review of the 
decision-making mechanisms in different arenas. This is so because of the relative weight that countries such as Brazil bring to bear on the processes of stabilization of their respective power subsystems, as well as the fact that these countries (particularly Brazil) hold diplomatic assets that are highly important for major agendas and negotiations. This is so, for instance, in regard to international trade, as well as to the environment, and more specifically, to climate change.

This kind of coordination shows the exact measure of an ambitious strategy of certain costs and doubtful gains. Brazil must prepare itself to have greater influence on international processes and specifically on the formulation of norms (without feeling constrained) that dramatically limit its interests as a regional power as well as its development possibilities. Accordingly, this explains the objective of a significant part of the major turns of Brazilian foreign policy in the Lula da Silva era: the pursuit of a permanent seat on the United Nations Security Council.

This is one of the three main ambitious objectives that explain the marked changes in the Brazilian system of bilateral relations since 2003. The other two ambitious objectives that have contributed to restore the universalist character of the country's international conduct until the early 1990s are related to economic expansion: (a) Restoration of the traditional trade channels (with Europe, United States, Japan, and South America, for instance) and the valorization of traditionally poorly explored economic relations (with Africa, China, the Arab World, and Asian regions, for instance); and (b) the opening of spaces for the operation of Brazilian business conglomerates, especially in strategic sectors (such as oil and ethanol).

These three lines of action required an extraordinary effort to expand bilateral ties in every direction. The first thing was the sophistication of the agenda of cooperation with traditional partners, especially with Europe, and to a lesser degree with China, India, Japan, and South Africa. The second was the extension of the diplomatic network to previously untouched limits, endowing with a priority political sense the establishment of new ties with countries and regions with which Brazil had historically maintained weak relations. Together, these two facets of the country's incorporation into the international scene with a universalist impetus led to a revaluation of the "strategic partnerships" concept.

\section{The strategic partnerships concept in Brazil's international experience}

The idea of "strategic partnerships" acquired an unequivocal meaning in Brazil's international experience in the 1970s and 1980s. It arose as a category of Brazilian diplomatic thinking in the context of the rapid change in relations with the United States under President Geisel (1974-1979). At that time, the idea became operational owing to the decision to speedily valorize relations with Eastern European countries, so as to mitigate the effects of the deterioration of the political and economic relationship with Washington. The movement had major consequences: it confirmed the importance of diversifying foreign links, 
which came to pass only under a system of bilateral relations of a universal cast (Lessa, 1995; Lima, 1996).

The strategic partnership with European countries, in turn, conceived as an escape valve for the tensions from bilateral relations with the United States, did not survive the changed international political and economic situation in the late 1970s. Nevertheless, it allowed interesting experiments from a political standpoint, such as the nuclear agreement with Germany (1975) and the involvement in the discussion about a new international economic order, which did not prosper either.

In the economic sphere, when the consequences of the first oil shock (1973) could still be felt, the dynamics of approximation with the European countries allowed the reversion of the United States's historical preponderance in trade and investment flows into Brazil. As a result of this and of the consolidation of the universalizing opening then adopted (pursuit of new relationships, opening toward Africa, recognition of the People's Republic of China, etc.), Brazil managed to secure a more balanced incorporation into the international scene - or at least established highly diversified economic ties.

This first experiment in "strategic partnerships" with European countries was the first movement that firmed up this concept in Brazilian diplomatic thinking. It can be said that this first generation of "partnerships" established the prototype of relationships called strategic. From this standpoint, strategic partnerships are "priority political and economic relations, reciprocally compensating, established on the basis of an accumulation of bilateral relations of a universal nature. The building of strategic partnerships rests on the harmonization of Brazil's historical calling for universalism and the need for selective approximations, which ensures the possibility of adaptation to the niches of opportunity and to international constraints arisen from circumstances (Lessa, 1998)."

The concept of strategic partnerships thus established itself in Brazilian diplomatic thinking with a definitive meaning. A historical analysis of foreign policy relates it to the search for inputs for the national development strategy (Cervo, 2008). Thus, the expression's vulgarization led to its inconsequential use in the diplomatic discourse, especially as of the 2000s. Now diplomacy expects to inject a sense of opportunity and urgency into the political discourse and the economic relationship with as many "partners" as seem to be useful in the current aggiornamento of Brazil's international profile.

$\mathrm{Be}$ as it may, either from the perspective of historical analysis or in light of a careful examination of experiments under way, the expression "strategic partnerships" today needs further clarification. This is all the more obvious in view of the proliferation of ties that in the Brazilian government's view (especially since 2004) deserve to be called "strategic." After all, what kind of relationship deserves to be so called?

It can be noticed also that during the Lula era, the strategic partnerships concept has served to the carrying out of a spectacle-inclined diplomacy. This is 
illustrated by the focus on the achievement of complex objectives of quite uncertain results, such as the pursuit of a permanent seat on the United Nations Security Council. This pursuit is particularly on its own behalf but it is also moved by the desire to project a new international image of a responsible regional power and emerging economy attuned to market values and endowed with attributes that qualify it as an actor ready to participate in the dynamics of stabilization of the international system in its multiple dimensions. Accordingly, the country has sought an international protagonist role, for which the "vulgarization" of the concept of strategic partnerships may have been useful.

The epistemological problem raised by this "new generation" of strategic partnerships is precisely the loss of meaning and importance of the concept as it was established by Brazil's international experience. A strategic partnership thus ceases to be an expression of a bilaterally defined agenda around political convergence and economic projects and becomes a mere label. It may happen that under this label complex projects and potentially valid agendas may be implemented, but it would be expected that essentially normative views of the relationship's reality in question would predominate. It is thus necessary to establish a new framework for future bilateral relations, possibly determined by political coordination mechanisms (regular summit meetings and joint commissions) and by specific agendas (energy, sustainable development, trade, investments, etc.)

This is not the place to make an exhaustive assessment of these ties, but there is a clear, nearly self-evident measure for them. Thus, empirical reality, which would permit testing the strategic partnership concept in Brazil's international praxis, could be obtained by an examination of the trade and investment flows, the density of political dialogue, the potential of scientific and technological cooperation, the dialogue channels, the convergence of agendas at multilateral forums, and the involvement in joint development projects.

\section{Fundamental partnerships: United States and Argentina}

The most fundamental system of Brazilian bilateral relations, on whose basis the intensity of ties with other countries may be measured, has been historically related to the United States. It may be said that this is a "fundamental partnership", which gives rise to the need for diversification of external ties and to the very historical process of building strategic partnerships (Lessa, 1998).

From this standpoint, relations with the United States should be classified as a "structuring relationship" because its development over the long term gives a measure of the intensity and organization of the entire system of Brazil's international relations, especially in the period from 1945-1990.

Relations between Brazil and the United States have undergone significant changes since the 1990s. These changes can be explained by the difference in the management of a relationship that had been built in the previous thirty years as 
a basically contentious relationship. As a matter of fact, bilateral relations had deteriorated to such a degree in the late 1980s, involving issues such as market access, science and technology, intellectual property, foreign debt, and development financing that this rapidly contaminated the rather poor political dialogue. The fact is that the two traditional partners were already following different courses in respect of punctual issues since at least the late 1950s. This pattern of disagreement can be explained by many factors, including the loss of economic complementariness, one of the major reasons.

Stabilization of relations with the United States, which began under the Fernando Henrique Cardoso administration (1994-2000), permitted the setting up of a positive agenda that incorporated the management mode traditionally characterized by tension peaks. Thus, the change had to do rather with the improved dialogue conditions and with the adoption of a specific mode of managing these relations, referred to by Hirst and Pinheiro (1995) as the "right to diverge." It is true that the United States still ranked highest among Brazil's economic partners, but for some decades relations were no longer characterized by economic dependence on the part of Brazil. This was also due to the stimulus to and prioritizing of political and economic relations with other developed countries (particularly with European countries).

As it was to be expected, there were problems in the handling of bilateral relations, connected with processes in which Brazil was involved. Governments tend to differ on trade issues, as illustrated by the episode of the negotiation of the Free Trade Area of the Americas - FTAA as well as of trade liberalization, especially in the World Trade Organization's context. In such cases, the mere existence of a multilateral framework (as for instance the rounds of negotiations aimed at trade liberalization and the WTO's dispute settlement mechanism) favored the empting of a possibly conflictive potential of bilateral relations regarding some of the burning issues on the contemporary international agenda.

There arose then a tendency to compartmentalize the bilateral agenda into two well-defined sectors: in the political negotiations between governments lie the differences regarding regional political processes (in the 1990s, the Colombian issue; in the 2000s, Venezuela's case; and more recently, the Honduras episode), migrations, international security, etc. On the more general level of views of the international political processes, countries tend to differ about the great issues of international politics, where there is still a large grey area characterized by the differences as to the very importance of political multilateralism, institutions, and the achievement of a multipolar order. What is new in the management of bilateral relations is the fact that these compartments do not communicate with each other as they did before. Thus, the differences over the agenda and its implementation remain isolated and rarely compromise the overall quality of relations.

Relations with Argentina could also be easily qualified as strategic. But there are certain specificities that make Brazil's relations with its major neighbor 
unique, which could also be properly described as "a structuring relationship." Indeed, relations with Argentina have conditioned the development of Brazilian policy toward South America, and the extraordinary transformation they have undergone since the 1980s has acquired a historic meaning, so that they could be described as a genuine Brazilian strategic partnership.

The Brasilia-Buenos Aires axis became a vector of South America's stabilization, established upon the review and normalizing of bilateral relations since the casting away of reciprocal mistrust and the heralding of a new phase of convergence aimed at economic integration. Equally complex, relations with Argentina spearheaded Brazil's regional activity, in both the political and the economic areas, and provided a basis for projects developed by Brazil on trade integration, security, and measures of political cooperation with other South American countries. These coordination mechanisms assumed different forms in the last two decades (Mercosur, Free Trade Area of the Americas - FTAA, South American Community of Nations-CASA, Union of South American Nations-Unasur).

Under the Lula government it has no longer been possible to separate the development of relations with Argentina from the development of regional integration mechanisms. Mercosur has tended to lose relevance on the overall list of Brazilian international priorities. At the same time, Argentina lost the first trade flow positions to Brazil, while providing room for the expansion of great Brazilian conglomerates, especially in the financial and energy sectors.

Mercosur has been assigned no priority in the Brazilian diplomatic discourse under Lula. This economic space has been absorbed by the development of South American regional mechanisms, such as Unasur. Mercosur has thus become a difficult project to manage, to the point that several influential sectors in Brazil now openly call for its reduction to a free trade zone. It is argued that this might be advantageous to Brazil, in so far as the country would recover the capacity to negotiate free trade agreements with more important partners, such as the United States and the European Union.

The Argentine government under Néstor Kirchner fiercely resisted Brazil's attempt at becoming the instrument of leadership in South America as a diplomatic asset. Cristina Kirchner, on the other hand, has been more pragmatic as to the potential "Brazilian ascent" to a global level and has wagered on restoring the quality of the relationship with Lula's Brazil. In some segments of Argentine public opinion it has been possible to detect greater understanding of the gains that could be derived from Brazil's protagonist role for their country, Mercosur, and South America.

\section{New strategic partnerships}

In recent years, the Brazilian government has sought to stamp as "strategic" its traditional relations with some countries. A far from exhaustive survey (Brasil, 
Repertório, 2007) specially valorized this in relations with Asian powers (Japan, India, and China) and with the main European countries, namely, France, Portugal, Spain, United Kingdom, and Italy, in addition to Russia. Brazil also maintains a "strategic partnership "with South Africa, and with it and India it forms the Group of Three (IBSA). But other countries have also been named "strategic partners" - South Korea, Venezuela, Paraguay, Ukraine, Finland, Sweden, Denmark, and Norway.

But it is possible to suppose, in view of the growing number of countries that have been named "strategic partners" in the diplomatic discourse, that the expression has been vulgarized and soon made into a style device by diplomacy and its agents. Used in an imprecise, abusive way, the expression begins to lose its meaning derived from historical experience and no longer signals importance, relevance, and priority in foreign policy's strategic thinking (Abreu, 2008).

Some representative cases will now be looked into: Japan, China, India, South Africa, and the European Union.

\section{Japan}

The establishment of a strategic partnership with Japan, of great potential, was interrupted in the early 1980's in view of the first signs of the Brazilian economic crisis. The great project of this partnership was cooperation for Brazil's agricultural development under the Japanese-Brazilian Cooperation Program for the Development of the Cerrados (Prodecer), conceived in 1974. Cooperation was not uninterested, of course, as the Japanese wanted to encourage the entry of a new player in the global grain market and thereby attenuate their nearly total dependence on the United States. Be as it may, both this program and the Japanese economic presence in Brazil are key components of an overall view of Brazilian development in the last three decades.

Economic relations with Japan lost their impetus in the 1980s and remained at the same level until 2005. On the other hand, an intense political agenda was kept, owing to a great extent to the question of the dekasseguis, the growing community of Brazilians of Japanese descent who migrated to Japan beginning in the 1980s in search of work opportunities. Trade indicators never grew to a significant degree, and investment flows remained below their potential.

The bilateral political and economic agenda gained a new impulse as of 2005 . Two factors explain why Japan was included again on the list of Brazil's strategic priorities. First, there was the perception on the part of the Japanese foreign policy operators that their country had actually lost major economic positions and conditions of dialogue with Brazil. Not less important, was the broaching of some initiatives that helped bring the two countries together again: the formation of the Group of 4, consisting of Brazil, Japan, Germany, and India, all four aspiring to a permanent seat on the United Nations Security Council; and the choice of 
the digital TV system in Brazil, potentially worth billions of dollars, which was decided in favor of the Japanese.

\section{China}

Brazil's relations with the People's Republic of China date back to 1974, when the Ernesto Geisel's government recognized the Chinese government and for the first time established Brazilian diplomatic relations with China. This meant a break with the position Brazil had maintained since 1949, of systematic support to the international isolation of the great Communist country. Though these relations are mature and long-standing, major joint projects under these relations were lacking.

China had intermittently signaled promise under Brazil's international relations system, or at least until 1993, when the Itamar Franco government decided to make Asia in general into a priority region for Brazil's international activity, and this was reiterated under both the Fernando Henrique Cardoso and the Lula Administrations. Since 1995, China has acquired a unique status in the strategic thinking of Brazilian foreign policy, given its cooperation potential in the area of Science and Technology and the magnitude of its trade.

The development of the remote sensing satellite-CBERS (in two generations launched respectively in 1999 and in 2003) illustrates the nature of this relationship, which indeed holds an immense cooperation potential. One of the major gestures toward the strategic valorization of relations with China was made by President Lula who paid a State visit to China in 2004, taking with him the largest entourage ever of Brazilian businessmen on this kind of mission. Brazil supported China's admission to the World Trade Organization, in the belief that this would indirectly contribute to the strengthening of the world trade system, because, given China's immense domestic market, the Chinese might agree to compromises that would benefit the developing countries (Oliveira, 2004).

A key element in Brazil-China relations beginning under the Lula government is the potential for political cooperation in different aspects, and this makes this relationship into a true strategic partnership. In addition to being a permanent member of the United Nations Security Council, thus holding veto power to bar reforms in the organization's structure, China has systematically sided with Brazil in respect of various issues and negotiation processes under the contemporary international agenda.

China has consistently grown as regards Brazilian trade flows in recent years, rapidly gaining top positions in the ranking of Brazil's major trade partners. As a result of the economic crisis that has harmed Brazil-United States relations, in April 2010 China for the first time ranked first in our trade relations, surpassing the United States. This fact does not really constitute a tendency, as Brazil's relations with its traditional partners (United States and Europe) are much better balanced, but nevertheless reflects the dynamism of Sino-Brazilian partnership. 
China is not only one of the greatest exporting countries, but also one of the world's greatest importers as well. Currently the Chinese import in excess of US $\$ 1$ trillion, which certainly means open doors to all the sectors of Brazilian economy, principally manufactures and consumer goods, in addition to basic products, such as iron ore and soybean. Brazil's greatest challenge is precisely the need to balance its trade list, as it exports basically primary products (about 70 percent of Brazilian exports consist of iron ore and soybean, whereas 95 percent of its imports consist of manufactures).

\section{India and South Africa}

Brazil's bilateral relations with India and South Africa have not been historically important, though long-standing. On both sides, there has been lack of dynamism and priority establishment. For different reasons, the two countries were assigned low priority under Brazilian foreign policy: Asia, where preferential ties were established with Japan; and Africa, a continent where Brazil's expansion came late and was motivated principally by the needs of trade expansion.

India and Brazil have a history of political cooperation since the 1960s; it is highly dynamic at multilateral forums, especially in respect of international trade negotiations. But their economic relations have been decisively marginal in the second half of the $20^{\text {th }}$ century and until the 2000s. India entered the political debate about Brazil's international choices as of the 1990s, when the country realized the need to reorganize its presence in Asia and particularly its relations with continent-size countries that began to emerge politically and economically. The first systematic approximation with a view to prioritizing bilateral ties beyond potential cooperation at multilateral forums was initiated by the Fernando Henrique Cardoso government. This approach had an economic component, which did not develop properly, as well as a political coordination mechanism, which did not go much further either.

Relations with South Africa were dynamic until the early 1970s, when the Brazilian government decided to keep its distance from the South African segregationist regime that, as could be noticed then, hindered a consistent policy of approximation to the rest of the African continent. Starting then, Brazil systematically kept its distance from South Africa and joined the international majority that condemned apartheid. This situation lasted until the end of the regime, with Nelson Mandela's election, and the normalization of South Africa's international profile in 1995. The effort to reactivate bilateral relations has since included a restoration of the trade flows and the attempt at injecting dynamism into the political dialogue, but the truth is that at that time Brazil still attached low priority the African region and South America was still an unknown region to South Africa (Penna Filho, 2001).

Reactivation of Brazil's relations with South Africa and India gained a new impetus early under the Lula government. In June 2003, the Ministry of Foreign 
Relations announced the launching of the India-Brazil-South Africa - IBSA Dialogue Forum. This initiative was conceived as a coordination mechanism primarily of a political nature among the three countries, which, more than ever, are believed to have a greater potential for cooperating than for competing. They are three intermediary countries, regional powers, multiethnic, multicultural democracies that can derive mutual benefit from coordinated actions in different areas, as well as from exchanging experiences related to economic and social development.

The IBSA Forum is grounded on a conceptually interesting argument and rests on converging political positions and on the three countries' potential for economic cooperation. This is certainly a model of trilateral strategic partnership, based on cooperation mechanisms and on the exchange of experiences with challenges common to all three.

\section{Europe}

The announcement of the establishment of the European Common Market in 1957 caused the greatest concern on the part of the Brazilian government, which was fully convinced that European integration would entail a significant drop in exports of coffee and other traditional products. This would happen due to the redirection of trade to the benefit of our African competitors, which would be favored by measures of trade association that would guarantee them privileged access (under the provisions of Arts. 131-136 of the Treaty of Rome), not only into France and Belgium but also into most partners, including two of Brazil's major trade partners in the world, namely, Germany and Italy (Lessa, 1998).

This less than auspicious beginning defined the character of the history of Brazilian relations with the European integration process in its earlier decades. Whereas Brazil's bilateral relations with the European States flowed unimpeded, free since then of trade disputes (which had been significant in some cases, such as with France), this heavy agenda, over which the parties seldom agreed, was reinforced precisely by the establishment of the European Common Market (Bueno, 1994).

The establishment of the Common Market entailed a major rupture of the European nucleus of Brazilian bilateral relations: it produced an axis of conflict, previously inexistent, which survived practically until the mid-1990s, centered on the handling of trade issues, especially market access and tariff treatment (Lessa, 1998). During this long period, there was no talk of political cooperation, as Latin America in general constituted a blind spot on the list of European community's international priorities.

On the other hand, it was at that moment that Brazil established relations with a significant number of European countries. These relations rapidly evolved into innovative forms of political and economic cooperation, as shown, for 
instance, by the diversification of foreign links established under the Ernesto Geisel government (1974-1979) (Lessa, 1995).

Those were the first steps toward strategic partnerships, as the Brazilian diplomatic thinking would conceive it: a strategic partnership with European countries was as a matter of fact conceived strictly as an escape valve for the tensions caused by the bilateral relationship with the United States, but did not survive the change in the international political and economic circumstances of the late 1970s.

Since then Brazil's interaction with the countries of Europe's western nucleus (France, Great Britain, Germany, Italy, Spain, Portugal, The Netherlands, and Belgium) proceeded at two different paces but was gradually normalized, consistently with the peculiarities of the bilateral agendas. Contacts with the Community as a whole, on the other hand, evolved very little and much more slowly: Brazil established diplomatic relations with the Community in 1960 and very little happened thereafter. A somewhat limited cooperation agreement with the Community was signed twenty years later and entered into force in 1982, but was replaced by a Cooperation Framework Agreement in 1995, which was the instrument governing contacts between Brazil and the European Community until 2007.

In the early 1990s, when integration experiments in South America had already advanced, the European Union's priorities envisaged the establishment of an agenda of cooperation with Mercosur. In this regard, the establishment of Mercosur in 1991 was a major factor for the reformulation of the European Community's relations with Latin America in general. This can be explained by the South American bloc's emergence as Europe's major trade partner and destination of European investments in the region.

Thus, still in 1992, an inter-institutional Cooperation Agreement was signed, which was followed by an Interregional Cooperation Framework Agreement. The coordination of interests continued in June 1999 with the first Summit Meeting of Heads of State and Chiefs of Government of the European Union and Latin America and the Caribbean. On that occasion, a Bi-Regional European UnionMercosur Negotiation Committee was established, for the purpose of liberalizing trade relations, with a view to the future signing of an inter-regional association agreement (Saraiva, 2004). An inter-regional partnership was thus established, encompassing the mechanisms of political contacts between the European Union and Latin America and the Caribbean (bi-regional summits) and the ministerial meetings of the Rio-European Union Group (Valle, 2005).

Brazil's growing international profile in recent years, coupled with the tiredness of the formula of dialogue used by the European Union with Latin America and the Caribbean (asymmetry of the integration processes, disparity in trade flows, political and economic heterogeneity of the Latin American actors) and the stagnation of negotiations with Mercosur led Brussels to abandon the 
traditional model of cooperation with the region. Thus, in late 2005, the European Union, after reviewing its overall relations with Latin America, decided to privilege Brazil as the region's key country.

Brussels view of Latin America was based on a perception of historic and structural homogeneity which did not match the region's political and economic circumstances, and this probably impeded the fluidity of the bi-regional dialogue. From the aggiornamento of this view came the decision to individualize the political relationship with the region's major countries, such as Brazil and Mexico, which would reignite contacts between the two regions, through the definition of clearer political objectives (Europe, European Commission, 2005).

The maturing of this view led to the adoption of the model already applied to the European Union's relations with its main interlocutors - the United States, Canada, Japan, Russia, China, and India - that is, relations in the form of a strategic partnership. As expressed by European diplomacy, these relations are characterized by "the range of bilateral contacts and the intensity of political and commercial ties and are built on a complex network of institutionalized forums and thematic dialogues that incorporate from technical working groups to meetings of Heads of State and Chiefs of Government (Barthelmess, 2008).”

It was then recognized that the maintenance of insufficient structures of bilateral political dialogue with Brazil was not consistent with the profile the country was displaying in international policy, and more specifically, with its apparent distancing from Latin American political and economic reality.

The announcement of the Brazil-European Union strategic partnership broke the cycle of paralysis of the European policy toward Latin America. The announcement took place in Lisbon, on July 4, 2007, on the occasion of the BrazilEuropean Union Summit Conference, which brought together the European Council's Troika and President Luiz Inácio Lula da Silva. The truth is that this new tie is of major importance for Brazil, which although it was not singled out among the emerging powers (as a matter of fact it was the last one of them to be so distinguished), now has conditions for individualized dialogue as an important actor in contemporary international policy (Brasil, MRE, 2007).

The expression "strategic partnership" is rather loosely used in the European Union's jargon and documents. The countries recognized as European Union's strategic partners are indeed privileged political interlocutors, of different statures, but acknowledgedly important for the realization of the interests of Europe's international action. Four of the European Union's strategic partners (Canada, United States, Japan, and Russia) form part of the group of major industrial countries, the Group of 8; three are permanent members of the United Nations Security Council (United States, Russia, and China); three (Japan, India, and Brazil) aspire to a permanent seat on the Security Council, should the latter be reformed; and four (Brazil, China, India, and Russia) are the major emerging economies today, and form the bloc known as BRIC. 
Moreover, the European Union is the main trade partner of five of these major economies: United States, China, Russia, India, and Brazil. Canada, owing to its preferential ties under the NAFTA, and Japan have the United States as their main trade partner, followed by the European Community.

\section{Conclusion}

Brazil's incorporation into the international scene has undergone major adjustments in the Lula era. In addition to new projects, such as southern coalitions, as exemplified by the IBSA Forum, and the ambition to win a seat on the United Nations Security Council, one can observe a line of continuity with the foreign policy of the governments of the 1990s. There has been some change in style, which however has not been sufficient to revolutionize Brazil's international action.

Lula's Brazil benefited from the consolidation of tendencies of international policy from the preceding decade: the ascension of the great markets, the emergence and centrality of new issues, and the valorization of multilateral spaces, for instance. This has permitted the consolidation of a profile that was being timidly sketched and the assumption of a protagonist role in different environments. The instrumentation of diplomatic assets recently created or reconverted from traditional international praxis has also been highly relevant for the aggiornamento of the management of Brazil's relations with its traditional partners and for the building of new partnerships.

The qualifier "strategic" as a synonym of special, important, and necessary matches a vision of political and economic cooperation projects based on a sense of opportunity but whose effects will last. Thus, Brazil's strategic partnerships, taken into account in an assessment of the Lula government's foreign policy, may be more than tools of an involved diplomacy. They may be associated with shared worldviews and sound results for the national development strategy, reinforcing the capacity for autonomous international action.

\section{Bibliography}

BARTHELMESS, Eugênia (2008). Brasil e Uniāo Européia: a construção de uma parceria estratégica. Tese apresentada ao LIII Curso de Altos Estudos do Instituto Rio Branco Ministério das Relações Exteriores. Brasília: Mimeo, 205 pp.

BRASIL (2007). Ministério das Relações Exteriores. Secretaria de Planejamento Diplomático. Repertório de Política Externa: Posiçôes do Brasil. Brasília: Mimeo, 160 pp.

BUENO, Clodoaldo (1994). A política multilateral brasileira. In: CERVO, Amado Luiz (org.). O desafio internacional: a política exterior do Brasil de 1930 a nossos dias. Brasília: Editora Universidade de Brasília, pp. 59-144.

CERVO, Amado Luiz (2008). Inserção internacional: formação dos conceitos brasileiros. 1. Ed. São Paulo: Saraiva, 297 p. 
EUROPA. Comissão Européia (2005). "Uma Parceria Reforçada entre a União Européia e a América Latina”. Available at http://eur-lex.europa.eu/LexUriServ/LexUriServ. do?uri=COM:2005:0636:FIN:PT:PDF (accessed on 01/15/2009).

HIRST, M. \& PINHEIRO, L. (1995). A Política Externa Brasileira em Dois Tempos. Rev. bras. polit. int., Brasília, v. 38, n. 1, pp. 5-23, Junho 1995.

LESSA, Antonio Carlos (1995). A estratégia de diversificação de parcerias no contexto do Nacional-desenvolvimentismo (1974-1979). Rev. bras. polit. int., Brasília, v.38, N. 1, pp.24-39.

LESSA, Antonio Carlos (1996). Da apatia recíproca ao entusiasmo de emergência: as relações Brasil-Europa Ocidental no Governo Geisel (1974-1979). Revista Anos 90, v.5, pp.89 - 106.

LESSA, Antônio Carlos (1998). A diplomacia universalista do Brasil: a construção do sistema contemporâneo de relações bilaterais. Rev. bras. polit. int., Brasília, v. 41, n. spe. Available at <http://www.scielo.br/scielo.php?script=sci_arttext\&pid=S0034-73291998000300003\&ln $\mathrm{g}=$ en \&nrm=iso $>$. accessed on Sept. 01/2010. doi: 10.1590/S0034-73291998000300003.

LIMA, Maria Regina Soares (1996). Brazil's Response to the "New Regionalism”. In: MACE, Gordon \& THÉRIEN, Jean-Philippe. Foreign Policy and Regionalism in the Americas. Boulder, Colorado: Lynne Rienner Publishers, pp. 143-144.

OLIVEIRA, Henrique Altemani de (2004). Brasil-China: trinta anos de uma parceria estratégica. Rev. bras. polit. int., Brasília, v. 47, n. 1, June. Available at <http://www.scielo. $\mathrm{br} /$ scielo.php? script $=$ sci_arttext $\&$ pid $=$ S0034-73292004000100002\&lng $=$ en $\& \mathrm{nrm}=\mathrm{iso}>$. accessed on Sept. 03 /2010. doi: 10.1590/S0034-73292004000100002.

PENNA FILHO, Pio (2001). África do Sul e Brasil: diplomacia e comércio (1918-2000). Rev. bras. polit. int., Brasília, v. 44, n. 1, June. Available from <http://www.scielo.br/scielo. php? script $=$ sci_arttext $\&$ pid $=$ S0034-73292001000100006\&lng $=$ en $\& \mathrm{nrm}=$ iso $>$. Accessed on Sept. 01/2010. doi: 10.1590/S0034-73292001000100006.

RODRIGUES, Diego de Freitas (2010). Cooperação horizontal Sul-Sul: arranjos de concertação política entre a Índia, o Brasil e a África do Sul. Rev. bras. polit. int., Brasília, v. 53, n. 1, July. Available at <http://www.scielo.br/scielo.php?script=sci_arttext\&pid=S0034$73292010000100003 \& \operatorname{lng}=$ en $\&$ nrm $=$ iso $>$. Accessed on Sept $01 / 2010$. doi: 10.1590/S003473292010000100003 .

SARAIVA, Miriam Gomes (2004). A União Européia como ator internacional e os países do Mercosul. Rev. bras. polit. int., Brasília, v. 47, n. 1, June. Available at <http://www.scielo. $\mathrm{br} /$ scielo.php? script $=$ sci_arttext \&pid $=$ S0034-73292004000100005\&lng = en \& nrm $=$ iso $>$. Accessed on Sept. 14/2010. doi: 10.1590/S0034-73292004000100005.

VALLE, Valeria Marina (2005). O peso das relações inter-regionais com a Uniāo Européia em relação a outras alternativas de política externa do Mercosul. Rev. bras. polit. int. 48, no. 1. doi:10.1590/S0034-73292005000100004. http://www.scielo.br/scielo.php?script=sci_ arttext\&pid $=$ S0034-73292005000100004\&lng=en\&nrm =iso.

Received July $1^{\text {st }}, 2010$ Accepted November 11, 2010 


\begin{abstract}
This article examines the priority bilateral relations of Brazil, named "strategic partnerships", both because of their tradition and historical relevance and due to the existence of political and economic cooperation projects. An assessment of these relationships, especially under Lula's administration, is made in this work, bearing in mind the concept of "strategic partnerships" and its development in Brazilian foreign policy. There will be considered partnerships with the US; Argentina; Japan; China; India; South Africa and the European Union. In the article, the meaning of the increase in these relationships is interpreted on the grounds of its significance to the international insertion strategy of Brazil.
\end{abstract}

\title{
Resumo
}

No trabalho são examinados os relacionamentos bilaterais prioritários do Brasil, que receberam a denominação de "parcerias estratégicas", tanto por causa da sua tradição e relevância histórica, quanto por causa da existência de projetos de cooperação política e econômica. A partir da elaboração do conceito de "parcerias estratégicas", e de como ela se construiu na política externa brasileira, neste trabalho se propõe um balanço desses relacionamentos especialmente durante a administração Lula da Silva (2003-2010). São examinadas as parcerias com os Estados Unidos, Argentina, Japão, China, Índia, África do Sul e União Européia. Propõe-se uma interpretação sobre o significado que o incremento desses vínculos possui para a estratégia de inserção internacional do País.

Key-words: strategic partnerships; bilateral partnerships; Brazilian foreign policy.

Palavras-chave: parcerias estratégicas; parcerias bilaterais; política externa brasileira. 